\title{
PENGARUH PEMBERIAN ENERGI, KARBOHIDRAT, PROTEIN, LEMAK TERHADAP STATUS GIZI DAN KETERAMPILAN ATLET SEPAK BOLA
}

\author{
Renjani Gina Ramadhani, Etisa Adi Murbawani*) \\ Program Studi Ilmu Gizi Fakultas Kedokteran Universitas Diponegoro \\ Jl.Dr.Sutomo No.14, Semarang, Telp (024) 8453708, Email : gizifk@undip.ac.id
}

\begin{abstract}
Background: Good skills in soccer are very needed to accomplish the achievement. Nutritional status in soccer athletes can effect the performance on the match. Besides exercises, nutrition intake is considered to have an effect on the nutritional status and skills of soccer athletes.

Objective: The purpose of this study was to determine the effect of food intake on nutritional status and skills of soccer athletes.

Methods: An experimental study with one group pre and post test designed on soccer athletes in PPLP Central Java on June 2012. Food intake were given in 55\%-60\% carbohydrates, 15\%-20\% protein, 20\%-30\% fat. Anthropometry, physical fitness, skill (passing and dribbling), and nutrition intake were measured pre-and postintervention. The data obtained were analyzed by paired t-test and Pearson correlation.

Results: Eighteen subjects completed this study. Significant increase in energy intake $(p=0,000)$, carbohydrate ( $p=$ $0,000)$, protein $(p=0,000)$, fat $(p=0,000), B M I(p=0,000)$, percent body fat $(p=0,031)$, physical fitness $(p=0,038)$, and passing $(p=0,000)$, but no significant differences found on dribbling $(p=0,056)$ after a given intervention. There was no effect of energy, carbohydrate, protein, fat on nutritional status and skills of soccer athletes $(p>0.05)$. Conclusion: There was no effect of energy, carbohydrate, protein, fat on nutritional status and skills of soccer athletes.
\end{abstract}

Keywords: food intake; soccer skills; nutritional status; soccer athletes

\begin{abstract}
ABSTRAK
Latar belakang : Keterampilan yang baik dalam sepak bola sangat diperlukan dalam pencapaian prestasi. Status gizi atlet sepak bola berpengaruh terhadap penampilan permainan. Selain latihan, asupan makan diduga memiliki pengaruh terhadap status gizi dan keterampilan atlet sepak bola.

Tujuan : Penelitian ini bertujuan untuk mengetahui pengaruh asupan makan terhadap status gizi dan keterampilan atlet sepak bola.

Metode : Merupakan penelitian eksperimental one group pre and post test design pada atlet sepak bola PPLP Jawa Tengah pada bulan Juni 2012. Asupan makan yang diberikan karbohidrat 55\%-60\%, protein 15\%-20\%, lemak 20\%-30\%. Pengukuran antropometri, kesegaran jasmani, keterampilan (passing dan dribbling), asupan makan dilakukan sebelum dan setelah intervensi. Data dianalisis dengan uji paired t-test dan korelasi Pearson.

Hasil : Delapan belas subjek dapat menyelesaikan penelitian. Terdapat peningkatan rerata yang bermakna pada asupan energi $(p=0,000)$, asupan karbohidrat $(p=0,000)$, asupan protein $(p=0,000)$, asupan lemak $(p=0,000)$, $\operatorname{IMT}(p=0,000)$, persen lemak tubuh $(p=0,031)$, kesegaran jasmani $(p=0,038)$, dan passing $(p=0,000)$, tidak terdapat perbedaan rerata bermakna pada dribbling $(p=0,056)$ setelah intervensi diberikan. Tidak terdapat pengaruh pemberian energi, karbohidrat, protein, lemak terhadap status gizi dan keterampilan atlet sepak bola $(p>0,05)$.
\end{abstract}

Simpulan : Tidak terdapat pengaruh pemberian energi, karbohidrat, protein, lemak terhadap status gizi dan keterampilan atlet sepak bola.

Kata Kunci : asupan makan; keterampilan sepak bola; status gizi; atlet sepak bola

\section{PENDAHULUAN}

Pencapaian prestasi dalam olahraga sepak bola tergantung pada tingkat keterampilan taktis, teknik, serta kesegaran jasmani para pemainnya. ${ }^{1}$ Keterampilan pemain sepak bola berkaitan dengan kemampuan penguasaan maupun pengembangan teknik dasar dalam permainan sepak bola yang diantaranya meliputi teknik menendang bola, menghentikan bola, menerima bola, menyundul bola, menggiring bola (dribbling), mengoper bola (passing), serta teknik khusus untuk penjaga gawang. ${ }^{2}$ Tingkat keterampilan atlet dipengaruhi oleh tingkat kesegaran jasmani. ${ }^{3}$

Kesegaran jasmani merupakan suatu keadaan yang dimiliki oleh seseorang untuk melakukan aktivitas fisik tanpa kelelahan yang

${ }^{*}$ Penulis Penanggungjawab 
berlebihan. $^{4}$ Kesegaran jasmani yang baik merupakan suatu hal yang tidak dapat diabaikan dalam pertandingan sepak bola, sehingga memiliki kesegaran jasmani yang baik pada masing-masing pemain merupakan suatu keharusan. ${ }^{5}$ Penelitian yang dilakukan pada atlet sepak bola Persatuan Sepak Bola Indonesia Semarang (PSIS) menunjukkan $57,8 \%$ atlet memiliki kategori kesegaran jasmani baik dan baik sekali sebesar sedangkan sebesar $42,2 \%$ tergolong sedang, kurang dan kurang sekali. ${ }^{6}$ Penelitian lain yang dilakukan pada siswa Sekolah Sepak Bola (SSB) di Malang menunjukkan bahwa hanya 20,4\% siswa yang memiliki kesegaran jasmani baik dan baik sekali sedangkan sisanya sebesar $79,6 \%$ siswa memiliki kesegaran jasmani sedang, kurang, dan kurang sekali. ${ }^{7}$ Atlet sepak bola yang berada di asrama rata-rata memiliki kesegaran jasmani yang lebih baik dibandingkan dengan atlet yang tidak di asrama. $^{8}$

Status gizi yang baik diperlukan untuk mempertahankan derajat kesegaran jasmani dan kesehatan serta menunjang pembinaan prestasi atlet. Pengukuran Indeks Massa Tubuh (IMT) dan persen lemak tubuh dapat menggambarkan status gizi seseorang. Beberapa penelitian yang dilakukan pada atlet sepak bola memunjukkan bahwa atlet yang memiliki IMT dan persen lemak tubuh optimal memiliki kesegaran jasmani yang lebih baik. $^{6-8}$

Asupan makan atlet sepak bola merupakan hal penting yang perlu diperhatikan selain latihan. Asupan zat gizi tidak memberikan jaminan bahwa atlet dapat meraih prestasi, tetapi apabila asupan zat gizi tidak mencukupi akan berpengaruh pula terhadap performa atlet karena atlet tidak dapat menggunakan kemampuan yang dimiliki secara maksimal meskipun program latihan yang dijalani sudah sesuai. ${ }^{9}$ Tingginya intensitas latihan dan jadwal pertandingan yang padat perlu didukung dengan pengaturan makan yang baik agar atlet mendapatkan asupan zat gizi yang sesuai untuk mencapai tingkat kesegaran jasmani dan status gizi yang optimal. ${ }^{10}$ Usia remaja merupakan masa pertumbuhan, sehingga pada atlet usia remaja membutuhkan energi tingkat tinggi untuk mendukung pertumbuhan dan aktivitas olahraga. ${ }^{11}$

Pembinaan atlet sepak bola dengan sistem asrama diharapkan mampu memberikan program latihan yang tersusun dengan baik diikuti dengan pengaturan asupan zat gizi yang terpantau dengan baik. Salah satu pusat pembinaan atlet sepak bola yaitu Pusat Pendidikan dan Pelatihan Pelajar (PPLP) Jawa Tengah. Beberapa prestasi yang diraih oleh tim sepak bola PPLP Jawa Tengah diantaranya Juara 1 Kejuaraan Nasional di Semarang, dan Juara 2 Pekan Olahraga Pelajar Nasional di Pekanbaru pada tahun 2011.

Pemenuhan gizi pada atlet sepak bola yang di PPLP Jawa Tengah belum terpenuhi dengan baik. Berdasarkan penelitian yang dilakukan terhadap 20 atlet sepak bola PPLP Jawa Tengah menunjukkan bahwa terdapat $70 \%$ atlet mengalami defisiensi energi tingkat berat dan $30 \%$ atlet mengalami defisiensi energi tingkat sedang. Ratarata asupan energi atlet tersebut 2770-2843 kkal, sedangkan energi yang dibutuhkan sebesar 41764354 kkal. $^{12}$

Penelitian mengenai pengaruh asupan makan terhadap keterampilan atlet sepak bola belum banyak dilakukan. Secara umum penelitian ini memiliki tujuan untuk mengetahui pengaruh pemberian energi, karbohidrat, protein, lemak terhadap status gizi dan keterampilan atlet sepak bola.

\section{METODE PENELITIAN}

Penelitian ini merupakan penelitian eksperimental one group pre and post test design yang dilakukan di Pusat Pendidikan dan Latihan Pelajar (PPLP) Jawa Tengah pada bulan Juni 2012 pada atlet sepak bola usia 15-18 tahun. Penelitian ini termasuk dalam lingkup gizi masyarakat. Pemilihan subjek penelitian dilakukan dengan teknik consecutive sampling, seluruh atlet sepak bola PPLP Jawa Tengah yang memenuhi kriteria inklusi dan bersedia mengikuti penelitian menjalani intervensi.

Penelitian dilakukan selama 13 hari dengan sebelas hari intervensi asupan makan dan dua hari pengambilan data awal dan akhir. Pengambilan data pengukuran awal dan akhir berupa survei asupan makan, pengukuran antropometri (berat badan, persen lemak tubuh, dan tinggi badan), penilaian tes kesegaran jasmani dan keterampilan. Gambaran asupan makan subjek penelitian diperoleh dengan menggunakan food recall 24 jam yang dilakukan sebelum dan selama intervensi dilakukan. Berat badan diukur dengan timbangan injak digital ketelitian $0,1 \mathrm{~kg}$. Persen lemak tubuh diukur menggunakan Bioelectrical Impedance Analysis (BIA) Omron HBF 200. Pengukuran berat badan dan persen lemak tubuh dilakukan dengan melepas alas kaki dan tetap mengenakan pakaian. Tinggi badan diukur dengan microtoise ketelitian $0,1 \mathrm{~cm}$, dengan posisi berdiri tegak dan pandangan lurus ke depan. Kesegaran jasmani yang diukur merupakan kesegaran jasmani 
berkaitan dengan keterampilan, meliputi tiga aspek pengukuran yaitu kapasitas anaerobik, daya ledak otot, kelincahan. Pengukuran kapasitas anaerobik dilakukan dengan lari cepat (sprint) 50 meter. Lari cepat diukur catatan waktu yang dibutuhkan untuk berlari dari titik start hingga finish menggunakan stopwatch dengan ketelitian 0,01 detik. Pengukuran daya ledak otot dilakukan dengan loncat tegak (vertical jump). Loncat tegak dilakukan sebanyak dua kali pengulangan dan hasil yang diambil adalah hasil terbaik dari dua loncatan yang dilakukan. Pengukuran kelincahan dilakukan dengan lari zig zag melewati rintangan dan catatan waktu diukur menggunakan stopwatch dengan ketelitian 0,01 detik. Hasil dari ketiga aspek ini kemudian dikategorikan sehingga didapatkan hasil tingkat kesegaran jasmani. Keterampilan sepak bola diukur dengan dua aspek penilaian yaitu passing dan dribbling bola. Passing bola dilakukan tiga kali kemudian dicatat waktu yang diperlukan untuk menyelesaikan passing bola secara tepat. Dribbling bola dilakukan dengan menggiring bola melewati rintangan dari titik start hingga finish, hasil yang diperoleh adalah waktu yang diperlukan untuk melakukan dribbling bola dari titik start hingga mencapai finish. Catatan waktu diukur menggunakan stopwatch dengan ketelitian 0,01 detik.

Intervensi yang diberikan dalam penelitian ini berupa asupan makan yang diberikan sesuai dengan rata-rata kebutuhan atlet sepak bola yang dihitung berdasarkan berat badan, tinggi badan, serta aktivitas fisik yaitu sebesar 4469,7 kkal \pm 10\% (4022,1 kkal-4915,9 kkal) dengan komposisi karbohidrat 55\%-60\%, protein $15 \%-20 \%$, lemak 20\%-30\% dari total energi. Asupan makan diberikan dalam bentuk tiga kali makan utama dan tiga kali snack. Jadwal makan utama disesuaikan dengan ketentuan yang telah ditetapkan oleh pengelola katering. Snack diberikan pagi hari setelah latihan, siang hari setelah latihan, dan malam hari setelah makan malam.

Data yang diperoleh kemudian dianalisis menggunakan program komputer. Data terlebih dahulu diuji normalitas menggunakan SaphiroWilk. Perbedaan asupan makan, status gizi, kesegaran jasmani, dan keterampilan baik sebelum maupun setelah intervensi diuji menggunakan paired t-test apabila data berdistribusi normal menggunakan uji Wilcoxon bila data tidak berdistribusi normal. Hubungan asupan energi, karbohidrat, protein, lemak terhadap status gizi dan keterampilan dianalisis dengan uji kolerasi Pearson. Data asupan makan diperoleh melalui food recall kemudian dianalisis menggunakan program nutrisurvey.

\section{HASIL PENELITIAN \\ Karakteristik Subjek Penelitian}

Penelitian dilakukan pada 24 atlet sepak bola PPLP Jawa Tengah . Dari jumlah tersebut hanya 21 orang yang memenuhi kriteria inklusi. Selama penelitian berlangsung terdapat 3 orang subjek yang tidak dapat melanjutkan penelitian karena 2 subjek pulang ke rumah masing-masing dan 1 orang sakit sehingga tidak mengikuti tes pada pengambilan data akhir penelitian. Data akhir yang diperoleh dan dapat dianalisis adalah 18 orang.

Karakteristik subjek penelitian ditampilkan pada Tabel 1 yang meliputi rerata tinggi badan, berat badan, indeks massa tubuh, persen lemak tubuh, asupan energi, kebutuhan energi, asupan protein, asupan lemak, kesegaran jasmani yang berkaitan dengan keterampilan, passing dan dribbling bola yang merupakan bagian dari tes keterampilan.

Tabel 1. Karakteristik Subjek Penelitian

\begin{tabular}{|c|c|c|c|}
\hline Karakteristik subjek & $\mathrm{n}$ & Rerata \pm SD & $\begin{array}{c}\text { Median } \\
\text { (minimum - maksimum) }\end{array}$ \\
\hline $\begin{array}{llll}\text { Indeks } & \text { Massa } & \text { Tubuh } & \text { (IMT) } \\
\left(\mathrm{kg} / \mathrm{m}^{2}\right) & & & \end{array}$ & 18 & $21,8 \pm 2,56$ & $21,64(18,68-28,94)$ \\
\hline Persen lemak tubuh $(\%)$ & 18 & $16,5 \pm 2,72$ & $17,05(11,10-21,00)$ \\
\hline Asupan energi (kkal) & 18 & $2509,0 \pm 522,79$ & $\begin{array}{l}2432,05(1772,80- \\
3373,80)\end{array}$ \\
\hline Kebutuhan energi (kkal) & 18 & $4468,1 \pm 378,59$ & $\begin{array}{l}4334,70(4028,70- \\
5442,20)\end{array}$ \\
\hline Asupan karbohidrat (g) & 18 & $411,7 \pm 90,31$ & $400,40(295,50-596,30)$ \\
\hline Asupan protein (g) & 18 & $73,3 \pm 15,52$ & $71,70(48,80-100,10)$ \\
\hline Asupan lemak (g) & 18 & $65,8 \pm 15,84$ & $63,30(45,80-92,40)$ \\
\hline Kesegaran jasmani (skor) & 18 & $9,4 \pm 0,70$ & $9,00(8,00-11,00)$ \\
\hline
\end{tabular}




\begin{tabular}{llll} 
Passing bola (detik) & 18 & $25,8 \pm 1,48$ & $25,63(23,73-29,59)$ \\
Dribbling bola (detik) & 18 & $27,6 \pm 1,75$ & $27,42(25,06-32,31)$ \\
\hline
\end{tabular}

Pengukuran indeks massa tubuh menunjukkan rerata indeks massa tubuh subjek $21,8 \pm 2,56 \mathrm{~kg} / \mathrm{m}^{2}$. Berdasarkan kurva persentil indeks massa tubuh menurut umur (5-19 tahun) diketahui status gizi sebagian besar subjek $(83,33 \%)$ tergolong normal. Rerata persen lemak tubuh subjek adalah $16,5 \pm 2,72$. Hasil pengukuran menunjukkan bahwa sebagian besar subjek $(72,22 \%)$ memiliki persen lemak tubuh normal (10-18\%), dan (27,77\%) subjek memiliki persen lemak tubuh lebih dari normal.

Hasil perhitungan kebutuhan subjek, didapatkan rerata kebutuhan energi sebesar $4468,1 \pm 378,59 \mathrm{kkal}$. Berdasarkan food recall 2x24 jam menunjukkan bahwa rerata asupan energi subjek sebesar 2509,0 $\pm 522,79$ kkal, asupan karbohidrat $411,7 \pm 90,31 \mathrm{~g}$, asupan protein $73,3 \pm 15,52 \mathrm{~g}$, asupan lemak $65,8 \pm 15,84 \mathrm{~g}$. Sebagian besar subjek $(83,33 \%)$ mengalami defisiensi energi tingkat berat dengan asupan kurang dari $70 \%$ kebutuhan energi.
Median skor tes kesegaran jasmani adalah 9,0 dengan skor tertinggi 11 dan skor terendah 8 . Sebagian besar subjek $(55,55 \%)$ memiliki kesegaran jasmani yang tergolong sedang (skor 89). Hasil pengukuran keterampilan menunjukkan rerata waktu yang diperlukan untuk melakukan passing bola adalah $25,8 \pm 1,48$ detik dengan catatan waktu tercepat 23,73 detik dan waktu terlama 29,59 detik. Rerata waktu yang diperlukan untuk melakukan dribbling bola adalah 27,60 $\pm 1,75$ detik, dengan catatan waktu tercepat 25,06 detik dan waktu terlama 32,31 detik.

\section{Perbedaan Hasil Pengukuran Sebelum dan Setelah Intervensi}

Perbedaan asupan energi, karbohidrat, protein, dan lemak subjek sebelum dan setelah intervensi ditampilkan dalam Tabel 2.

Tabel 2. Perbedaan Rerata Dan Simpang Baku Sebelum dan Setelah Intervensi

\begin{tabular}{lllccc}
\hline \multirow{2}{*}{ Pengukuran } & \multicolumn{3}{c}{ Rerata \pm SD } & \multirow{2}{*}{$\Delta$} & $p$ \\
\cline { 2 - 3 } & Sebelum & Setelah & & \\
\hline Asupan energi (kkal) & $2509,0 \pm 522,79$ & $4055,9 \pm 167,88$ & 1546,9 & $0,000^{*}$ \\
Asupan karbohidrat (g) & $411,7 \pm 90,31$ & $636,9 \pm 40,45$ & 225,2 & $0,000^{*}$ \\
Asupan protein (g) & $73,3 \pm 15,52$ & $124,0 \pm 10,40$ & 50,7 & $0,000^{*}$ \\
Asupan lemak (g) & $65,8 \pm 15,84$ & $126,2 \pm 8,24$ & & 60,4 & $0,000^{*}$ \\
Indeks Massa $\quad$ Tubuh & $21,8 \pm 2,56$ & $22,0 \pm 2,54$ & & 0,2 & $0,000^{*}$ \\
(IMT) (kg/m ${ }^{2}$ ) & & & & \\
Persen lemak tubuh (\%) & $16,5 \pm 2,72$ & $16,9 \pm 2,51$ & & 0,4 & $0,031^{*}$ \\
Dribbling bola (detik) & $27,6 \pm 1,75$ & $26,6 \pm 1,58$ & 1,0 & 0,056 \\
\hline
\end{tabular}

*Paired $t$-test terdapat perbedaan yang bermakna $(p<0,05)$

Berdasarkan hasil analisis statistik menunjukkan bahwa terdapat perbedaan yang bermakna pada rerata asupan energi $(p=0,000)$, karbohidrat $(\mathrm{p}=0,000)$, lemak $(\mathrm{p}=0,000)$, dan protein $(\mathrm{p}=0,000)$ sebelum dan setelah intervensi. Keseluruhan subjek mengalami peningkatan berat badan diikuti dengan meningkatnya indeks massa tubuh setelah intervensi. Terdapat perbedaan rerata indeks massa tubuh yang bermakna sebelum dan setelah intervensi $(p=0,000)$. Pada pengukuran persen lemak tubuh, terjadi kenaikan persen lemak tubuh pada empat belas subjek $(77,77 \%)$, dari jumlah tersebut sepuluh subjek masuk dalam kategori normal, empat subjek masuk dalam kategori lebih dari normal. Hasil analisis statistik menunjukkan bahwa terdapat perbedaan rerata persen lemak tubuh yang bermakna sebelum dan setelah intervensi $(\mathrm{p}=0,031)$. Tidak terdapat perbedaan rerata yang bermakna pada tes dribbling bola sebelum dan setelah intervensi $(\mathrm{p}=0,056)$.

Perbedaan hasil tes kesegaran jasmani dan passing bola pada subjek sebelum dan setelah intervensi ditampilkan dalam Tabel 3. 
Tabel 3. Perbedaan Median Sebelum dan Setelah Intervensi

\begin{tabular}{|c|c|c|c|c|}
\hline \multirow{2}{*}{ Pengukuran } & \multicolumn{2}{|c|}{ Median (minimum - maksimum) } & \multirow{2}{*}{$\Delta$} & \multirow{2}{*}{$p$} \\
\hline & Sebelum & Setelah & & \\
\hline $\begin{array}{lr}\text { Kesegaran } & \text { jasmani } \\
\text { berkaitan } & \text { dengan } \\
\text { keterampilan (skor) }\end{array}$ & $9,00(8,00-11,00)$ & $10,00(9,00-12,00)$ & 1,00 & $0,038^{*}$ \\
\hline Passing bola (detik) & $25,63(23,73-29,59)$ & $\begin{array}{l}24,08(23,12- \\
27,36)\end{array}$ & 1,55 & $0,000^{*}$ \\
\hline
\end{tabular}

*Wilcoxon terdapat perbedaan yang bermakna $(p<0,05)$

Hasil analisis statistik pengukuran kesegaran jasmani berkaitan dengan keterampilan menunjukkan bahwa terdapat perbedaan kesegaran jasmani antara sebelum dan setelah intervensi $(p=$ 0,038). Terdapat sembilan subjek yang memiliki kesegaran jasmani dengan skor tetap baik sebelum dan setelah intervensi, delapan subjek mengalami peningkatan kesegaran jasmani setelah intervensi, dan satu orang mengalami penurunan kesegaran jasmani setelah intervensi. Pada tes passing bola, keseluruhan subjek memiliki catatan waktu yang lebih cepat setelah intervensi. Hasil analisis menunjukkan bahwa terdapat perbedaan catatan waktu pada passing bola sebelum dan setelah intervensi $(\mathrm{p}=0,000)$.

Hubungan Variabel Bebas, Variabel Kontrol, dan Variabel Terikat

Hubungan antara asupan, IMT, persen lemak tubuh, dribbling bola ditampilkan dalam Tabel 4.

Tabel 4. Hubungan antara asupan, IMT, persen lemak tubuh, dan dribbling bola

\begin{tabular}{llllll}
\hline & & \multicolumn{1}{c}{$\begin{array}{c}\text { Asupan } \\
\text { energi }\end{array}$} & \multicolumn{1}{c}{$\begin{array}{c}\text { Asupan } \\
\text { karbohidrat }\end{array}$} & $\begin{array}{c}\text { Asupan } \\
\text { lemak }\end{array}$ & $\begin{array}{c}\text { Asupan } \\
\text { protein }\end{array}$ \\
\hline IMT & $\mathrm{r}$ & $-0,158$ & $-0,149$ & 0,113 & 0,028 \\
& $p$ & 0,531 & 0,555 & 0,655 & 0,912 \\
Persen lemak tubuh & $\mathrm{n}$ & 18 & 18 & 18 & 18 \\
& $\mathrm{r}$ & $-0,185$ & $-0,217$ & 0,256 & 0,071 \\
& $p$ & 0,462 & 0,386 & 0,306 & 0,779 \\
Dribbling bola & $\mathrm{n}$ & 18 & 18 & 18 & 18 \\
& $\mathrm{r}$ & 0,233 & 0,235 & $-0,141$ & 0,255 \\
& $p$ & 0,353 & 0,348 & 0,576 & 0,307 \\
& $\mathrm{n}$ & 18 & 18 & 18 & 18 \\
\hline
\end{tabular}

Korelasi Pearson, terdapat hubungan bermakna $(p<0,05)$

Berdasarkan hasil uji statistik diketahui tidak terdapat hubungan yang bermakna antara asupan energi, karbohidrat protein, lemak dengan IMT, persen lemak tubuh, dribbling bola dengan nilai $p>0,05$.
Hugungan antara asupan, kesegaran jasmani, dan passing bola ditampilkan dalam Tabel 5.

Tabel 5. Hubungan antara asupan, kesegaran jasmani, dan passing bola

\begin{tabular}{llllll}
\hline & & $\begin{array}{c}\text { Asupan } \\
\text { energi }\end{array}$ & \multicolumn{1}{c}{$\begin{array}{c}\text { Asupan } \\
\text { karbohidrat }\end{array}$} & $\begin{array}{c}\text { Asupan } \\
\text { lemak }\end{array}$ & $\begin{array}{c}\text { Asupan } \\
\text { protein }\end{array}$ \\
\hline Kesegaran jasmani & $\mathrm{r}$ & $-0,169$ & $-0,414$ & 0,360 & 0,034 \\
& $p$ & 0,502 & 0,088 & 0,142 & 0,895 \\
Passing bola & $\mathrm{n}$ & 18 & 18 & 18 & 18 \\
& $\mathrm{r}$ & 0,234 & 0,416 & $-0,329$ & 0,166 \\
& $p$ & 0,349 & 0,086 & 0,182 & 0,510 \\
& $\mathrm{n}$ & 18 & 18 & 18 & 18 \\
\hline
\end{tabular}

Korelasi Spearrman, terdapat hubungan bermakna $(p<0,05)$ 
Berdasarkan hasil uji statistik diketahui tidak terdapat hubungan yang bermakna antara asupan energi, karbohidrat, protein, lemak dengan kesegaran jasmani, dan passing bola dengan nilai $p>0,05$.

\section{PEMBAHASAN}

Pada penelitian ini melibatkan 18 subjek atlet sepak bola yang tergabung dalam satu kelompok perlakuan. Rerata usia subjek yaitu 17,3 $\pm 0,90$ tahun, dengan usia termuda 15 tahun dan subjek tertua berusia 18 tahun. Berdasarkan pengukuran antropometri didapatkan rerata indeks massa tubuh subjek $21,8 \pm 2,56 \mathrm{~kg} / \mathrm{m}^{2}$ dengan rerata persen lemak tubuh $16,5 \pm 2,72 \%$. Sebagian besar subjek $(83,33 \%)$ memiliki status gizi normal dan $72,22 \%$ subjek memiliki persen lemak tubuh normal. Rerata asupan energi subjek sebesar $2509,0 \pm 522,79 \mathrm{kkal}$, besarnya asupan energi subjek masih berada dibawah rerata kebutuhan $4468,1 \pm 378,59$. Sebagian besar subjek $(83,33 \%)$ mengalami defisiensi energi tingkat berat. Median skor tes kesegaran jasmani adalah 9,0. Sebagian besar subjek $(55,55 \%)$ memiliki kesegaran jasmani yang tergolong sedang (skor 8-9). Rerata waktu yang diperlukan untuk melakukan passing bola adalah $25,85 \pm 1,48$ dan untuk dribbling bola 27,6 $\pm 1,75$ detik.

Asupan makan subjek penelitian mengalami perubahan yang bermakna sebelum dan setelah intervensi diberikan. Rerata peningkatan asupan makan yaitu dari 2509,0 $\pm 522,79$ kkal menjadi 4055,9 $\pm 167,88 \mathrm{kkal}$. Rerata asupan makan subjek sebelum intervensi berada di bawah kebutuhan apabila dibandingkan dengan kebutuhan energi yang mempertimbangkan kebutuhan energi basal (BMR), Specific Dynamic Action (SDA), aktivitas fisik serta tambahan energi $10 \%$ untuk pertumbuhan. Sebelum intervensi diberikan sebagian besar subjek $(83,33 \%)$ mengalami defisiensi tingkat berat. Kurangnya asupan energi pada subjek dikarenakan ada faktor kurangnya kesadaran subjek terhadap kebutuhan energi yang harus terpenuhi dan peranan zat gizi dalam menunjang stamina. Setelah intervensi diberikan, sebagian besar subjek $(83,33 \%)$ memiliki kategori asupan baik. Asupan zat gizi tidak memberikan jaminan bahwa atlet dapat meraih prestasi, tetapi pemenuhan asupan zat gizi yang adekuat pada atlet usia remaja sangatlah penting karena kekurangan asupan zat gizi dalam jangka panjang akan mengganggu proses perkembangan, pertumbuhan, perkembangan otot, serta mempengaruhi performa. ${ }^{9}, 11$

Terjadi perubahan yang bermakna pada indeks massa tubuh subjek sebelum dan setelah intervensi. Perubahan ini terjadi seiring dengan peningkatan berat badan yang dialami oleh subjek. Rerata indeks massa tubuh subjek meningkat dari $21,8 \pm 2,56 \mathrm{~kg} / \mathrm{m}^{2}$ menjadi $22,0 \pm 2,54 \mathrm{~kg} / \mathrm{m}^{2}$. Peningkatan berat badan subjek bervariasi berkisar antara 100 gram hingga 1600 gram. Perubahan indeks massa tubuh yang bermakna pada subjek tidak mengubah status gizi yang dimiliki oleh subjek. Lima belas subjek memiliki status gizi yang normal sebelum dan setelah intervensi, dua subjek tetap memiliki status gizi gemuk, dan satu subjek tetap memiliki status gizi obesitas baik sebelum maupun setelah diberikan intervensi. Pada penelitian ini pemberian intervensi selama 11 hari hanya dapat melihat perubahan pada berat badan, dan tidak terdapat perubahan pada tinggi badan subjek. Dibutuhkan penelitian dengan waktu yang lebih panjang untuk dapat melihat perubahan yang terjadi pada status gizi.

Rerata persen lemak tubuh subjek mengalami peningkatan sebelum dan setelah intervensi dari $16,5 \pm 2,72 \%$ menjadi $16,9 \pm 2,51 \%$. Hal ini menunjukkan bahwa rerata persen lemak tubuh subjek masih dalam batas normal untuk atlet sepak bola $10 \%-18 \% .^{13}$ Sebagian besar subjek $(83,33 \%)$ memiliki persen lemak tubuh normal. Satu subjek yang memiliki status gizi obesitas memiliki persen lemak tubuh lebih dari normal. Dua subjek yang memiliki status gizi gemuk, salah satu diantaranya memiliki persen lemak tubuh lebih dari normal, sedangkan yang lain memiliki persen lemak tubuh normal. Hal ini sesuai dengan penelitian sebelumnya yang menunjukkan bahwa status gizi gemuk pada atlet tidak selalu mengindikasikan semakin meningkatnya jumlah cadangan lemak dalam tubuh tetapi dapat terjadi karena meningkatnya massa otot. ${ }^{14}$ Pada penelitian ini hanya melihat persen lemak tubuh pada atlet tetapi tidak dilakukan pengukuran terhadap massa otot, sehingga perbandingan massa otot dan massa lemak tidak dapat diketahui. Atlet dengan status gizi gemuk dan obesitas dengan persen lemak lebih dari normal dimungkinkan memiliki proporsi massa otot yang lebih tinggi dibandingkan massa lemak. Pada penelitian sebelumnya menunjukkan bahwa peningkatan indeks massa tubuh disebabkan oleh peningkatan persen lemak tubuh dan massa otot. $^{14}$ 
Posisi permainan dalam sepak bola turut mempengaruhi komposisi tubuh yang dimiliki oleh atlet sepak bola. ${ }^{15}$ Pada penelitian ini, subjek dengan status gizi gemuk dan persen lemak tubuh lebih dari normal menempati posisi sebagai penjaga gawang, sedangkan subjek yang memiliki status gizi obesitas dengan persen lemak tubuh lebih dari normal menempati posisi sebagai pemain bertahan. Pada penelitian sebelumnya menunjukkan bahwa penjaga gawang memiliki tinggi badan dan berat badan yang lebih dibandingkan dengan pemain lain. Postur badan tinggi besar dibutuhkan oleh penjaga gawang karena tugasnya menghalau bola masuk ke dalam gawang, selain itu ditemukan bahwa persen lemak tubuh yang dimiliki oleh penjaga gawang lebih tinggi dibandingkan pemain lain. Penjaga gawang dan pemain bertahan hanya bermain kurang dari setengah lapangan dan intensitas berlari lebih sedikit dibandingkan pemain depan sehingga penggunaan energi juga lebih sedikit, hal ini yang memungkinkan persen lemak tubuh yang dimiliki oleh penjaga gawang dan pemain bertahan lebih tinggi dibanding pemain tengah. ${ }^{16,17}$

Berdasarkan uji statistik tidak didapat pengaruh asupan makan terhadap indeks massa tubuh dan persen lemak tubuh, namun secara teori asupan makan memberikan pengaruh terhadap peningkatan indeks massa tubuh dan persen lemak tubuh. Peningkatan asupan energi sebesar 500 hingga $1000 \mathrm{kkal}$ yang disertai dengan latihan dapat meningkatkan berat badan atlet. ${ }^{18}$ Penelitian sebelumnya yang dilakukan pada atlet sepak bola menunjukkan bahwa peningkatan asupan, dapat meningkatkan berat badan dan persen lemak tubuh. ${ }^{19}$ Kelebihan energi pada saat melakukan aktivitas akan disimpan, umumnya disimpan dalam bentuk glikogen atau sebagai triasilgliserol di jaringan adiposa. Hal ini memungkinkan adanya peningkatan massa lemak tubuh yang menimbulkan terjadinya peningkatan berat badan diikuti dengan peningkatan indeks massa tubuh. ${ }^{20}$ Terjadinya peningkatan berat badan pada atlet tergantung pada faktor genetik, tingkat keseimbangan energi positif, jumlah waktu istirahat dan waktu pemulihan, serta jenis program latihan yang dijalani. ${ }^{18}$

Kesegaran jasmani merupakan komponen penting yang harus dimiliki atlet untuk mencapai prestasi. Tanpa kesegaran jasmani yang prima, prestasi akan sulit tercapai walaupun atlet memiliki keterampilan teknik dan taktik yang baik. ${ }^{5}$ Kesegaran jasmani yang diukur dalam penelitian ini adalah kesegaran jasmani berkaitan dengan keterampilan yang terdiri dari kapasitas anaerobik, daya ledak otot, dan kelincahan. Kapasitas anaerobik merupakan kemampuan tubuh untuk melakukan aktivitas dengan intensitas tinggi. Pengukuran kapasitas anaerobik dilakukan dengan lari cepat (sprint) 50 meter. ${ }^{21}$ Daya ledak otot yaitu kemampuan otot untuk berkontraksi dengan sangat cepat, merupakan kekuatan otot yang dikeluarkan secara maksimum dalam kecepatan maksimum. Daya ledak otot merupakan faktor penting yang digunakan untuk melompat maupun menendang bola. Pengukuran daya ledak otot dilakukan dengan loncat tegak (vertical jump). Kelincahan berhubungan dengan kemampuan mengubah dan mengontrol arah maupun posisi secara cepat dan efisien. ${ }^{22}$ Pengukuran kelincahan dilakukan dengan lari zig zag melewati rintangan. Rerata catatan waktu subjek dalam melakukan lari cepat $50 \mathrm{~m}$ menurun dari 6,94 $\pm 0,24$ detik sebelum intervensi menjadi 7,09 $\pm 0,30$ setelah intervensi, meskipun demikian catatan waktu lari cepat subjek tergolong baik. Rerata kemampuan loncat tegak subjek mengalami peningkatan dari $50,38 \pm 6,77 \mathrm{~cm}$ sebelum intervensi menjadi $52,05 \pm 5,97 \mathrm{~cm}$ setelah intervensi dengan kategori kurang. Rerata catatan waktu lari zig zag subjek mengalami peningkatan dari 6,30 $\pm 0,31$ detik dengan kategori baik menjadi $5,94 \pm 0,26$ detik setelah intervensi dengan kategori baik sekali.

Terjadi peningkatan kesegaran jasmani yang bermakna pada subjek setelah pemberian intervensi. Median skor kesegaran jasmani subjek mengalami peningkatan dari 9,00 (8,00-11,00) dengan kategori sedang menjadi 10,00 $(9,00$ 12,00) dengan kategori baik. Hasil dari tes kesegaran jasmani menunjukkan bahwa tidak semua atlet memiliki kesegaran jasmani dengan kategori baik. Diharapkan semua atlet sepak bola memiliki kesegaran jasmani yang baik untuk menunjang performa selama latihan maupun bertanding.

Pada penelitian ini terdapat perbedaan yang bermakna antara kesegaran jasmani sebelum dan setelah intervensi dilakukan, tetapi tidak terdapat pengaruh yang bermakna dari asupan zat gizi terhadap kesegaran jasmani. Tidak terdapatnya pengaruh yang bermakna dapat terjadi karena kesegaran jasmani dipengaruhi oleh banyak faktor diantaranya latihan fisik, genetik, komposisi tubuh. Pada penelitian ini tidak terdapat subjek yang memiliki kesegaran jasmani dengan kategori kurang, dimungkinkan faktor latihan fisik yang mempengaruhi kesegaran jasmani. Hal ini dikarenakan subjek telah memiliki program latihan 
fisik yang dijalani secara teratur dengan sebelas kali sesi latihan dalam satu minggu untuk mengoptimalkan komponen kesegaran jasmani seperti kecepatan, kekuatan, kelincahan, keseimbangan, koordinasi, daya ledak otot, kelenturan, daya tahan kardiorespirasi, serta daya tahan otot. Penelitian yang dilakukan pada remaja usia 17 hingga 20 tahun menunjukkan bahwa terdapat hubungan yang signifikan antara latihan fisik dan kesegaran jasmani, yaitu semakin tinggi frekuensi dan durasi latihan fisik maka tingkat kesegaran jasmani akan semakin baik. Latihan fisik yang terprogram bermanfaat untuk menjaga dan meningkatkan derajat kesehatan dan kesegaran jasmani. ${ }^{23}$ Latihan fisik merupakan bagian dari aktivitas fisik yang terencana, terstruktur, serta dilakukan secara berulang-ulang yang bertujuan untuk meningkatkan atau mempertahankan kesegaran jasmani. Latihan fisik yang berulang dan terus menerus akan menimbulkan reaksi biologis berupa penyesuaian diri atau adaptasi dari organorgan tubuh. ${ }^{24}$

Keterampilan teknik yang diukur dalam penelitian ini adalah keterampilan passing dan dribbling bola. Passing bola merupakan teknik mengalirkan atau mengoper bola, dalam passing bola diperlukan kekuatan (power), kecepatan, koordinasi mata-kaki. ${ }^{25}$ Dribbling merupakan keterampilan dalam menggiring bola. Diperlukan kekuatan, kelincahan, kecepatan, koordinasi matakaki, keseimbangan, kecepatan reaksi yang baik pada saat melakukan dribbling agar atlet dapat melakukan kontrol bola dengan baik sehingga bola tetap dalam penguasaan pada saat melewati lawan. $^{26}$

Keterampilan passing bola subjek penelitian mengalami perubahan yang bermakna sebelum dan setelah intervensi, dengan catatan waktu yang semakin cepat dari 25,63 detik menjadi 24,08 detik, artinya catatan waktu semakin cepat 1,55 detik. Tidak terdapat perbedaan yang bermakna pada dribbling bola sebelum dan setelah intervensi, tetapi terdapat peningkatan kecepatan dribbling bola sebelum dan setelah intervensi dari $27,60 \pm 1,75$ detik menjadi $26,61 \pm 1,58$ detik, terjadi peningkatan kecepatan 1,01 detik. Tidak terdapatnya perubahan yang berarti pada dribbling bola yang dilakukan oleh subjek dapat terjadi karena kemampuan dribbling pada subjek tidak hanya dipengaruhi oleh aspek kelincahan, daya ledak otot, serta kapasitas anaerobik yang diukur dalam penelitian ini, tetapi juga dipengaruhi oleh faktor lain yang tidak diukur dalam penelitian ini yaitu keseimbangan dan koordinasi mata-kaki.
Pada penelitian ini ditemukan bahwa terjadi peningkatan catatan waktu pada lari cepat 50 meter, yang memiliki arti terjadi penurunan kecepatan lari yang dilakukan oleh subjek. Penurunan performa lari cepat pada subjek tidak menurunkan performa pada keterampilan yaitu passing dan dribbling bola. Hal ini sesuai dengan penelitian sebelumnya yang menunjukkan bahwa penurunan performa lari cepat tidak menurunkan performa dribbling bola pada atlet sepak bola. Performa dribbling bola lebih membutuhkan teknik keterampilan dibandingkan dengan kapasitas daya tahan (endurande). ${ }^{27}$

Pada saat sebelum penelitian dengan asupan makan yang kurang dari kebutuhan tidak mempengaruhi kemampuan subjek dalam melakukan dribbling bola sehingga catatan waktu sebelum dan setelah intervensi dilakukan tidak berbeda secara bermakna. Pada penelitian sebelumnya yang meneliti mengenai pengaruh asupan tinggi karbohidrat terhadap kemampuan dribbling dan shooting atlet sepak bola, menemukan bahwa setelah pemberian asupan makan tinggi karbohidrat tidak terjadi peningkatan kemampuan dribbling dan shooting pada atlet sepak bola. ${ }^{28}$ Hal ini kemungkinan terjadi karena deplesi glikogen yang mungkin terjadi saat asupan makan kurang dari kebutuhan tidak mengurangi kemampuan keterampilan atlet. $^{29}$ Beberapa penelitian menemukan bahwa ketika seseorang melakukan olahraga dengan kondisi glikogen otot tubuhnya rendah, maka terjadi peningkatan transkripsi dari beberapa gen terkait dengan kontraksi otot yang terlibat dalam adaptasi tubuh selama berolahraga sehingga otot tetap dapat melakukan kontraksi. ${ }^{30-32}$ Hal ini terkait dengan faktor transkripsi yang terlibat yaitu domain pengikat glikogen, ketika glikogen otot rendah faktor-faktor ini akan dilepas dan menjadi bebas untuk berikatan dengan protein target yang berbeda. ${ }^{33}$ Pada kenyataannya, latihan dengan glikogen otot yang tinggi memungkinkan atlet untuk melakukan latihan dalam jangka waktu yang lama dan dapat mencapai hasil yang lebih baik. Asupan zat gizi yang optimal selama olahraga dan aktivitas sangat penting untuk menyediakan cadangan energi yang digunakan sebagai bahan bakar selama berolahraga sehingga atlet tidak mudah lelah. ${ }^{33,34}$

Tidak adanya pengaruh asupan makan terhadap keterampilan berupa passing dan dribbling bola pada subjek dimungkinkan adanya faktor lain yang mempengaruhinya. Keterampilan pada atlet lebih banyak dipengaruhi oleh faktor 
latihan yang dilakukan, subjek telah memiliki latihan rutin yang terprogram dengan baik. Latihan yang dilakukan secara berulang-ulang dapat meningkatkan dan memperbaiki keterampilan atlet sepak bola, sehingga tingkat keterampilan yang dimiliki tidak mudah menurun. ${ }^{35}$ Penurunan keterampilan seperti passing dan dribbling bola lebih dipengaruhi oleh faktor kelelahan karena dehidrasi maupun meningkatnya produksi asam laktat. $^{29}$

Berdasarkan hasil uji statistik terdapat beberapa korelasi negatif, yaitu hubungan antara asupan energi dengan indeks massa tubuh, persen lemak tubuh, dan kesegaran jasmani. Terdapat pula korelasi negatif antara asupan karbohidrat dengan indeks massa tubuh, persen lemak tubuh, dan kesegaran jasmani, serta korelasi negatif antara asupan lemak dengan passing dan drbbling bola. Hal ini dimungkinkan karena dipengaruhi oleh beberapa hal yang terjadi pada saat pengambilan data asupan makan.

Keterbatasan dalam penelitian ini adalah jumlah subjek penelitian yang minimal menyebabkan adanya kemungkinan bias dalam penelitian. Pengukuran persen lemak tubuh menggunakan BIA injak tidak dapat mengukur persen lemak tubuh secara keseluruhan.

\section{SIMPULAN}

Pada penelitian ini tidak didapatkan adanya pengaruh pemberian energi, karbohidrat, protein, lemak terhadap status gizi dan keterampilan pada atlet sepak bola. Rerata asupan energi, karbohidrat, protein, dan lemak subjek mengalami peningkatan yang bermakna sebelum dan setelah intervensi. Terjadi peningkatan yang bermakna pada rerata indeks massa tubuh subjek dan persen lemak tubuh subjek mengalami peningkatan bermakna sebesar.

Skor kesegaran jasmani subjek mengalami peningkatan sebelum dan setelah intervensi. Catatan waktu passing bola yang dilakukan subjek mengalami peningkatan yang bermakna sebelum dan setelah intervensi. Terjadi peningkatan pada catatan waktu dribbling bola, tetapi tidak terdapat perbedaan yang bermakna sebelum dan setelah intervensi.

\section{SARAN}

Penelitian lebih lanjut mengenai pengaruh pemberian energi, karbohidrat, protein, lemak terhadap status gizi dan keterampilan atlet sepak bola perlu dilakukan dengan jumlah subjek penelitian yang lebih banyak dan jangka waktu yang lebih lama, dengan mempertimbangkan faktor intensitas latihan yang dapat mempengaruhi keterampilan atlet sepak bola. Perlu adanya peningkatan pemahaman dan kesadaran pada atlet mengenai aturan pola makan yang benar secara kualitas maupun kuantitas untuk mencapai gizi yang seimbang.

\section{DAFTAR PUSTAKA}

1. Stolen T, Chamari K, Castagna C, Wisloff U. Physiology of soccer : an update. Sport Medicine. [serial online] 2005 [cited 2012 February 20]; 35(6); p.501-36. Available from URL: http://www.skautingtimdif.rs

2. Sucipto. Sepak Bola. Departemen Pendidikan dan Kebudayaan : Direktorat Jenderal Dikti; 2000.p. 17

3. Tomi V, Minna B, Keijo H. Development of body composition, hormone profile, physical fitness, general perceptual motor skills, soccer skills and on - the - ball performance in soccer specific laboratory test among adolescent soccer player. Journal of Sports Science and Medicine. [serial online] 2010 [cited 2012 March 29]; 9: p.547-56. Available from : URL: http:// www.jssm.org/vol9/n4/3/v9n4-3pdf.pdf

4. Clark JR. Positional assessment and physical fitness characteristic of male professional soccer players in South Africa. African Journal of Physical, Health Education, Recreation and Dance. [serial online] December 2007 [cited 2012 February 10]; 13(4); p. 453-64. Available from : URL : http://www.repository.up.ac.za.

5. Rosidi Ali. Hubungan status gizi, status kesehatan dan aktivitas fisik dengan kesegaran jasmani atlet PSIS Semarang [Tesis]. Institut Pertanian Bogor; 2000.

6. Fajar I, Tapriadi, I. N. Tami. Pola konsumsi, status gizi dan kesegaran jasmani siswa sekolah sepak bola di Malang [skripsi]. Edisi 29. Jakarta: Binadiknakes; 1998.

7. Sardjono W. Hubungan tingkat komsumsi energi, karbohidrat, BMI dan presentase lemak tubuh dengan tingkat kesegaran jasmani atlet sepakbola yunior pada periode latihan [skripsi]. Universitas Diponegoro Semarang; 2009.

8. Wulandari Tabitha SH. Pengaruh asrama atlet sepakbola terhadap status gizi (IMT dan kadar $\mathrm{Hb}$ ), aktifitas fisik dan kesegaran jasmani [Tesis]. Program Pascasarjana Universitas Diponegoro Semarang; 2004.

9. Sihadi. Sport and nutrition. Jurnal Kedokteran Yarsi. [serial online] 2006 [cited 2012 March 1]; 14(1); p.78-84. Available from : URL: http://www.repository.univpancasila.ac.id/dmdocu ments/Gizi\%2520dan\%2520olahraga.pdf.

10. Irawan MA. Nutrisi, energi dan performa olahraga. Polton Sports Science and Performance Lab. [serial online] 2007 [cited 2012 February 2]; [13 
screens]. Available from : URL :http:// www.pssplab.com/journal/04.pdf.

11. Primiana DA. Pemenuhan energi pada olahraga. Pedoman Pelatihan Gizi Olahraga untuk Prestasi. Jakarta : Departemen Kesehatan dan Kesejahteraan Sosial RI Direktorat Gizi Masyarakat; 2000.

12. Immawati A. Pengaruh pemberian sport drink terhadap performa dan tes keterampilan pada atlet sepak bola usia 15-18 tahun [skripsi]. Universitas Diponegoro Semarang; 2011.

13. Jeukendrup A, Michaele Gleeson. An introduction to energy production and performance. In : Sport Nutrition. USA : Human Kinetics; 2010. p.316

14. Pontaga Inese, Janis Zidens. Estimation of body mass index in team sports athletes. Lase Journal Of Sport Science. [serial online] February 2011 [cited 2012 July 6]; p. 33-44. Available from : URL : http://www.lspa.lv

15. Melchiorri G, Monteleone G, Andreoli A, Calla C, Sgroi M, De Lorenzo A. Body cell mass measured by bioelectrical impedance spectroscopy in professional football (soccer) players. Journal of Sports Medicine and Physical Fitness. [serial online] 2007 [cited 2012 August 22]; 47(4); p. 408-12. Available from : URL: http://cat.inist.fr/?aModele $=$ afficheN\&cpsidt=2003 2417

16. Heather HF, Lisa AB, Alan EM. Team Sport Athletes. In : Practical applications in sports nutrition. Boston : Jones And Bartlett Publishers; 2006. p. 431.

17. Sporis Goran, Igor Jukic, Sergej M Ostojic, Dragan Milanovic. Fitness profiling in soccer : physical and physiologic characteristics of elite players. Journal of Strength \& Conditioning Research. [serial online] October 2009 [cited 2012 July 30]; 23(7); p. 1947-53. Available from : URL : http://www.journals.lww.com

18. American Dietetic Association and Dietitians of Canada. Nutrition and athletic performance. American College of Sport Medicine. [serial online] 2000 [cited 2012 August 18]; p. 2130-45. Available from : URL http://aprendeenlinea.udea.edu.co

19. Garthe Ina, Truls Raastad, Per Egil Refnes, Jorunn Sundgot-Borgen. Effect of nutritional intervention on body composition and performance in elite athlete. European Journal of Sport Science. [serial online] 1 March 2012 [cited 2012 August 20]. Available form : URL : http:// www.tandfonline.com/doi/abs/10.1080/17461391. 2011.643923

20. Robert K. Muray, Daryl K. Granner, Victor W Rodwell. Biokimia Harper edisi 27. Jakarta : EGC; 2009. p. 290

21. Irawan MA. Metabolisme energi tubuh dan olahraga. Polton Sports Science and Performance Lab. [serial online] 2007 [cited 2012 February 2];
1(7); p 1-10. Available from : URL :http:// www.pssplab.com

22. Battinelli T. Aerobic and anaerobic conditioning. Wolinsky I, eds. Physique, fitness, and performance. Florida : CRC Press: 2000. P. 77-87

23. Shinichi Demura, Takayoshi Yamada, Shigeru Shimada, Masanobu Uchiyama. Influence of exercise habits and physical fitness level on subjective fatigue symptoms in adolescent students. Health. [serial online] 2011 [cited 2012 June 20]; 3(1); p. 20-25. Available from : URL : http://www.scrip.org/journal/HEALTH/

24. I Putu Panca Adi. Hubungan antara koordinasi gerak mata - kaki dan kekuatan otot tungkai terhadap ketepatan operan panjang dalam permainan sepak bola. Jurnal Penelitian dan Pengembangan Sains \& Humanoria. [serial online] 2007 [cited 2012 June 1]; 1(1); p.53-61. Available from

URL:http://www.freewebs.com/santyasa/Lemlit/P DF_Files/SAINS/AGUSTUS_2007/I_Putu_Panca Adi.pdf

25. Vanttinen T, Minna Blomqvist, Keijo Hakkinen. Development of body composition, hormone profile, physical fitness, general perceptual motor skills, soccer skills and on-the-ball performance in soccer specific laboratory test among adolescent soccer players. Journal of Sports Science and Medicine. [serial online] 2010 [cited 2012 February 10]; 9; p.547-556. Available from URL : http://www.jssm.org

26. Miller K. The effects on soccer dribbling skills when training with two different sized soccer balls [thesis]. University of Kansas; 2012

27. Katis A, Eleftherios Kellis. Effects of small-sided games on physical conditioning and performance in young soccer players. Journal of Sports Science and Medicine. [serial online] 2009 [cited 2012 August 30]; 8; p.374-380. Available from URL : http://www.jssm.org

28. Abt G, Shi Zhou, Robert Weatherby. The effect of a high-carbohydrate diet on the skill performance of midfield soccer player after intermittent treadmill exercise. Journal Science Medical Sport. [serial online] 1998 [cited August 1]; 1(4); p. 203 12. Available from : URL : http:// http://www.jsams.org/article/S14402440(09)60003-7

29. Mujika I, Louise M. Burke. Nutrition in team sports. Annals of Nutrition and Metabolism. [serial online] 2010 [cited 2012 August 1]; 57(2); p. 2635. Available from : URL http://www.ncbi.nlm.nih.gov/pubmed/21346334

30. Febbraio Mark A, Adam Steensberg, Rory Walsh, Irene Koukoulas, Gerrit van Hall, Bengt Saltin,et al. Reduced glycogen availability is associated with an elevation contracting human skeletal muscle. [serial online] February 2002 [cited 2012 August 5]; 538(3); p. 911-17. Available from : 
URL

http://www.ncbi.nlm.nih.gov/pmc/articles/PMC22 90094/

31. Charlotte K, Adam Steensberg, Henriette Pilegaard, Takuya Osada, Bengt Saltin, Bente KP, et al. Transcriptional activation of the IL- 6 gene in human contracting skeletal muscle: influence of muscle glycogen content. FASEB Journal. [serial online] 2001 [cited 2012 July 10]; 15; p. 2748-50. Available from : URL http://www.fasebj.org/content/15/14/2748.full

32. Pilegaard H, Keller C, Steensberg A, Helge JW, Pedersen BK, saltin B, Neufer PD. Influence of pre-exercise muscle glycogen content on exerciseinduced transcriptional regulation of metabolic genes. Journal of Physiology. [serial online] 2002 [cited 2012 August 3]; 541(1); p. 261-71. Available from : URL http://www.ncbi.nlm.nih.gov/pubmed/12015434

33. Hawley John A, Kevin D, Tipton, Mindy L. Promoting training adaptations through nutritional interventions. Journal of Sports Sciences. [serial online] July 2006 [cited 2012 August 20]; 24(7); p. 709-21. Available from : URL : http://www.sportsoracle.com/uploads/2610.pdf

34. Melzer Katarina, Bengt Kayser, Wim H.M. Saris, Claude Pichard. Effects of physical activity on food intake. Clinical Nutrition. [serial online] 2005 [cited 2012 August 17]; 24; p. 885-95. Available from : URL http://arno.unimaas.nl/show.cgi?fid=4396

35. Williams A. Mark, Nicola J. Hodges. Practice, instruction and skill acquisition in soccer : challenging tradition. Journal of Sports Sciences. [serial online] 2005 [cited 2012 August 21]; p. 115. Available from : URL : http://www.ncbi.nlm.nih.gov/pubmed/16195012 